\title{
Foraging behavior and ruminal fermentation of dairy cows grazing ryegrass pasture alone or with white clover
}

\author{
Henrique Mendonça Nunes Ribeiro Filho(1), Jean-Louis Peyraud(2) and Rémy Delagarde(2)
}

\begin{abstract}
(1)Universidade do Estado de Santa Catarina, Avenida Luiz de Camões, № 2.090, CEP 88520-000 Lages, SC, Brazil. E-mail: a2hrf@cav.udesc.br (2)Institut National de la Recherche Agronomique (INRA), UMR1080 INRA-Agrocampus Ouest, Production du Lait, Saint-Gilles, France. E-mail: jean-louis.peyraud@rennes.inra.fr, remy.delagarde@rennes.inra.fr
\end{abstract}

\begin{abstract}
The objective of this work was to evaluate the influence of pasture composition and regrowth age on the relationship between feeding behavior and ruminal fermentation in dairy cows grazing perennial ryegrass with or without white clover. The experiment was carried out in a $2 \times 2$ factorial arrangement, with two sward types and two ages of regrowth. Swards of perennial ryegrass sown alone (PRG) and of perennial ryegrass mixed with white clover (GC) were evaluated. Twelve late-lactation Holstein cows, fistulated at the rumen, were distributed in a $4 \times 4$ latin square experimental design with four 12-day periods. Daily distribution of grazing was similar in the PRG and the GC swards, but the concentration of rumen volatile fatty acids (VFA) was higher and the proportion of propionate was lower on mixed swards during the day. Daily distribution of grazing was similar in pastures of different ages. However, in the oldest swards, rumen fluid $\mathrm{pH}$ increased and VFA concentration decreased after evening milking. Time spent grazing does not influence ruminal fermentation, which depends on the changes that occur as different sward layers are grazed.
\end{abstract}

Index terms: Lolium perenne, Trifolium repens, digestion, grazing, grazing time.

\section{Comportamento ingestivo e fermentação ruminal em vacas leiteiras em pasto de azevém com e sem trevo branco}

\begin{abstract}
Resumo - O objetivo deste trabalho foi avaliar a influência da composição do dossel do pasto e da idade de rebrota sobre as relações entre as atividades de ingestão e a fermentação ruminal em vacas leiteiras, em pasto de azevém perene com ou sem trevo branco. Doze vacas da raça Holandesa, em final de lactação, fistuladas no rúmen, foram distribuídas em delineamento experimental de quadrado latino $4 \mathrm{x} 4$, com quatro períodos de 12 dias, em arranjo fatorial 2x2, com dois tipos de pasto - azevém perene em cultivo solteiro (AZ) e de azevém perene consorciado com trevo branco (TB) - e duas idades de rebrota. A distribuição diária do pastejo foi semelhante nos pastos AZ e TB, mas a concentração ruminal de ácidos graxos voláteis (AGV) foi maior e a proporção de propionato foi menor nos pastos em associação, ao longo do dia. A distribuição das atividades de pastejo foi semelhante nos pastos com idades diferentes. Entretanto, nos pastos mais velhos, o pH ruminal aumentou e a concentração de AGV diminuiu após a ordenha da tarde. O tempo de pastejo tem pouca influência sobre a fermentação ruminal, a qual depende de alterações que ocorrem à medida que os diferentes estratos são pastejados.
\end{abstract}

Termos para indexação: Lolium perenne, Trifolium repens, digestão, pastejo, tempo de pastejo.

\section{Introduction}

Grazing studies have shown that the milk yield of cows grazing mixed swards of ryegrass (Lolium perenne L.) and white clover (Trifolium repens L.) could be increased by 15 to $25 \%$, when compared with pure perennial ryegrass swards (Peyraud et al., 2009; Steinshamn, 2010). This enhanced performance is related to the increase of intake rather than to the nutritive value of the mixed swards (Ribeiro Filho et al., 2003; Dewhurst et al., 2009).
Higher herbage intake on mixed swards than on pure grass swards can be a result of a higher voluntary intake of clover in comparison to pure grasses (Institut National de la Recherche Agronomique, 2007), but also of a better prehensibility of the defoliated strata (Baumont et al., 2004). For the grazing cow, mixed swards could be more prehensible than grass swards, because the stolons of clover, contrary to the stem and the pseudostem of grasses, remain close to the ground, in the inaccessible and ungrazed layer (Orr et al., 2004). 
Therefore, the ingestive behavior at these swards, in a strip-grazing management, can be different from the one in rotational or continuous grazing, since the sward characteristics change more rapidly during the day.

Changes in ingestive behavior with a reduction in sward height have been associated to short-term adaptations, such as bite mass and intake rate reductions (Gregorini et al., 2009). In pure legume swards, higher intake rates may be related to differences in the morphological composition of the defoliated strata, when compared to ryegrass swards (Chapman et al., 2007). On mature swards, bite mass is affected by the presence of "barrier" components in the swards, including stems and dead material (Drescher et al., 2006). At long-term, Williams et al. (2005) compared the pattern of ingestive behavior of cows grazing Persian clover- or perennial ryegrass-dominant swards. However, information on the daily pattern of grazing at long-term and on the changes in ruminal fermentation characteristics of cows grazing mixed swards is limited.

The objective of this work was to evaluate the influence of pasture composition and regrowth age on the relationship between feeding behavior and ruminal fermentation in dairy cows grazing perennial ryegrass with or without white clover.

\section{Materials and Methods}

The experiment was carried out at the experimental farm of the Institut National de la Recherche Agronomique at Méjusseaume, near Rennes, Brittany, France, in a $4 \times 4$ balanced latin square experimental design, with four 12-day periods, in a $2 \times 2$ factorial arrangement, two types of swards and two ages of regrowth. The sward types evaluated were pure perennial ryegrass (PRG) and a mixture of perennial ryegrass and white clover (GC). The regrowth ages assessed were 19 and 35 days. Each experimental period comprised seven days for cow adaptation and five days for measurements.

Twelve late-lactation Holstein cows fistulated at rumen were evaluated, including four primiparous. The animals were divided into four homogeneous groups according to milk yield $(24.5 \pm 3.0 \mathrm{~kg})$, stage of lactation (218 \pm 18 days), milk protein content $\left(30.9 \pm 1.5 \mathrm{~g} \mathrm{~kg}^{-1}\right)$, and milk fat content $\left(37.4 \pm 5.6 \mathrm{~g} \mathrm{~kg}^{-1}\right)$, measured in the pre-experimental period. The initial live weight was $609 \pm 51 \mathrm{~kg}$.

One half of the 4.0-ha plot used in the experiment was sown with perennial ryegrass (Ohio cultivar) and the other half with a mixture of white clover and perennial ryegrass (Alice and Ohio cultivars, respectively). Before the beginning of the trial, non-experimental heifers grazed the entire plot, with a residual plate meter height of $4.0 \mathrm{~cm}$. The plot was then divided into 16 paddocks, one per type of sward, age, and period. Each paddock was grazed for one period only. According to the treatment, the paddocks were mown either 19 or 35 days before the tenth day of each period, corresponding to the average day for measuring foraging behavior and ruminal fermentation. Pre-experimental $\mathrm{N}$ fertilization was applied as follows. In late winter, after the first grazing with non-experimental heifers, $40 \mathrm{~kg} \mathrm{ha}^{-1}$ of $\mathrm{N}$, as ammonium sulfate, were applied over the entire plot (PRG and GC swards) to increase pasture growth rate. After that, $60 \mathrm{~kg} \mathrm{ha}^{-1}$ of $\mathrm{N}$ were applied only on the PRG paddocks, immediately after each pre-experimental mowing. The GC paddocks received no further $\mathrm{N}$ fertilization, since the $\mathrm{N}$ supplied by clover nitrogen fixation is considered sufficient. Four groups of cows were allowed to strip-graze throughout the trial, with an herbage allowance of $12 \mathrm{~kg}$ dry matter per cow per day at $5.0 \mathrm{~cm}$ above ground level, independently of the treatment. The grazing area offered each day for each group was calculated daily according to herbage mass estimation and to sward height and bulk density. Sward height was measured daily with a rising plate meter, and bulk density was measured three times per period. The front fencing was moved once per day in the morning, and the back fencing after a time lag of one day. Cows were milked twice a day at $7 \mathrm{~h} 30$ and at 17h30. Water was continually available, and a mineral block was available.

The daily pattern of grazing and ruminating was measured automatically over a 24-hour period, by recording jaw movements with a portable device. The 12 cows evaluated were equipped simultaneously for five consecutive days, starting at the eighth day, in order to obtain at least three complete recordings per period and cow.

Ruminal fermentations were monitored by measuring the $\mathrm{pH}$ as well as the concentrations of ammonia and volatile fatty acids (VFA) in rumen fluid. Ruminal fluid was sampled at $7 \mathrm{~h} 30,11 \mathrm{~h}, 14 \mathrm{~h} 30,17 \mathrm{~h} 30,21 \mathrm{~h} 30$, and 
0h. At each sampling, $50 \mathrm{~mL}$ of rumen fluid were drawn out through the cannula. The $\mathrm{pH}$ was immediately measured, and then the rumen fluid was filtered through six thicknesses of the muslin. For each cow, the filtrate was subsampled for the analysis of ammonia $(4.0 \mathrm{~mL}$ in $4.0 \mathrm{~mL}$ of $20 \% \mathrm{NaCl}$ preservative $)$ and VFA $(8.0 \mathrm{~mL}$ in $0.8 \mathrm{~mL}$ of a preservative made up of $\mathrm{HgCl}_{2} 1 \% \mathrm{~W} \mathrm{v}^{-1}$ in $\mathrm{H}_{3} \mathrm{PO}_{4} 5 \% \mathrm{v} \mathrm{v}^{-1}$ ). These samples were preserved at $-20^{\circ} \mathrm{C}$ until analysis. Ammonia and VFA were analyzed by the colorimetric and gas chromatography techniques, respectively.

Differences between treatments and sampling times were analyzed using the SAS software (Littell et al., 1998). Variables were analyzed as individual values by taking into account the following factors: cow, period, sward type, regrowth age, interaction between sward type and regrowth age, sampling time, interaction between grazing time and regrowth age, interaction between time and sward type, and interaction between time, regrowth age and sward type. Analyses were performed as repeated measurements. Period, sward type, and regrowth age were considered as fixed variables, whereas cow was considered as a random variable. Means were compared by the Student's t-test.

\section{Results and Discussion}

Sward type and regrowth age effects were additive for the pattern of foraging behavior and ruminal fermentation (interaction between sward type, regrowth age and time of day: $\mathrm{p}>0.10$ ).

The daily distribution of grazing and ruminating activity was similar between sward types (Figure 1). However, after morning milking, grazing time was shorter and ruminating time was longer on the GC swards in comparison to the PRG swards (interaction between sward type and time of day: $p<0.001$ ). After evening milking, grazing time was longer on the GC swards than on the PRG swards.

Despite a similar pattern of grazing behavior, ruminal VFA concentration was higher on the GC swards than on the PRG swards during the day (Figure 2). This result shows that under strip-grazing management the time spent grazing is a poor indicator of the intensity of ruminal fermentation, which could be associated to sward structural traits and to their effects on the intake rate (Baumont et al., 2004) and the chemical composition of herbage (Noziere et al., 2011). Under rotational stocking, the influence of sward height and of the leaf/stem ratio on bite mass is more highly correlated with green leaf mass than with sward surface height or total herbage mass (Gregorini et al., 2009). Likewise, the intake rate declines progressively as leaves are removed, and the pseudostem corresponds to a greater proportion of the ingested material (Drescher et al., 2006). In the present work, the height of extended tillers at post-grazing was similar between swards types, but the percentage of green leaf mass under $8.0 \mathrm{~cm}$ was higher in the GC swards than in the PRG swards.

There was no significant interaction between sward type and time of day $(\mathrm{p}>0.10)$ for rumen fluid $\mathrm{pH}$ and VFA. However, the proportion of propionate $(p<0.001)$, the proportion of acetate $(p<0.001)$, and the lipogenic and glucogenic VFA ratio (acetate + butyrate: propionate; $\mathrm{p}<0.001)$ differed between the PRG and the GC swards during the day (Figure 2).
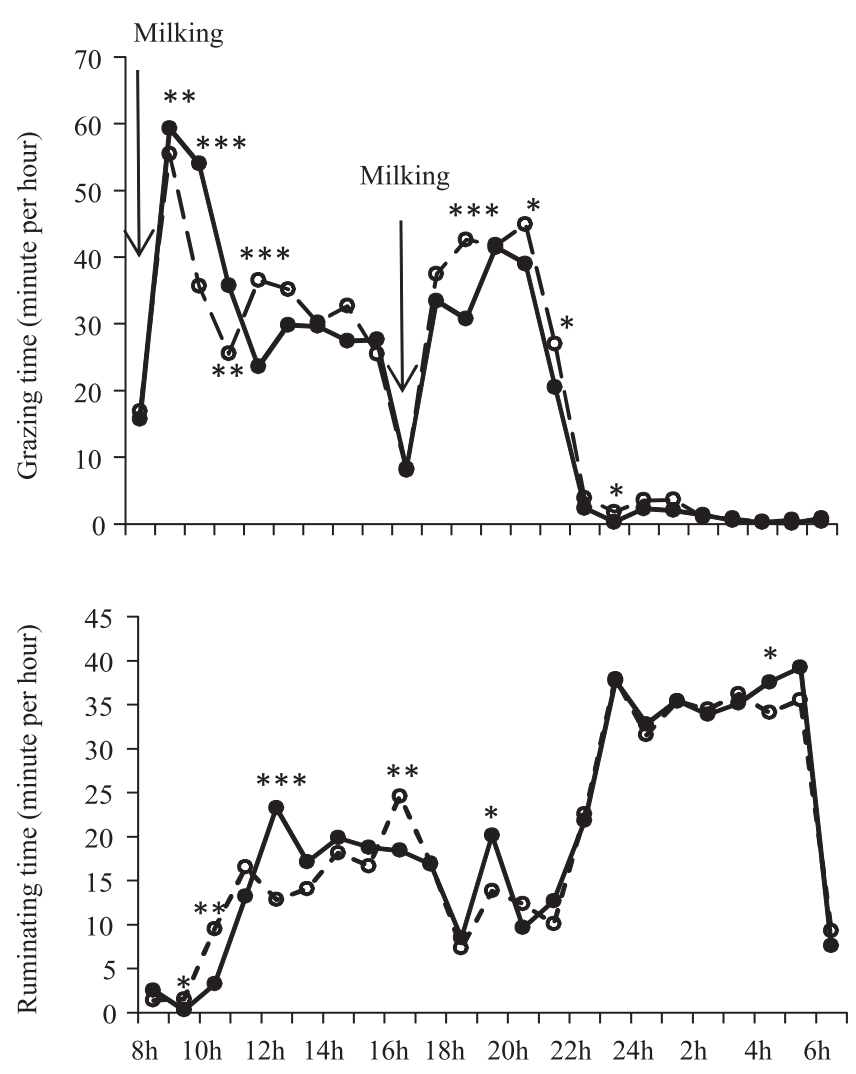

Figure 1. Diurnal grazing and ruminating patterns of cows grazing perennial ryegrass alone $(\bullet)$ or a mixture of perennial ryegrass and white clover $(0)$; for each time of day $*, * *$, and $* * *$ Significant at 5,1 , and $0.1 \%$ probability, respectively, by the Student's t-test. 
In both sward types, rumen fluid $\mathrm{pH}$ decreased and VFA increased between morning and evening milking. Molar proportions of propionate increased more intensively in the PRG swards after morning milking and remained higher than $21 \%$ at night. For the GC swards, the molar proportion of propionate was lower than $21 \%$ during the day. Therefore, during the day, the acetate + butyrate: propionate ratio was lower in the PRG swards than in the GC swards.
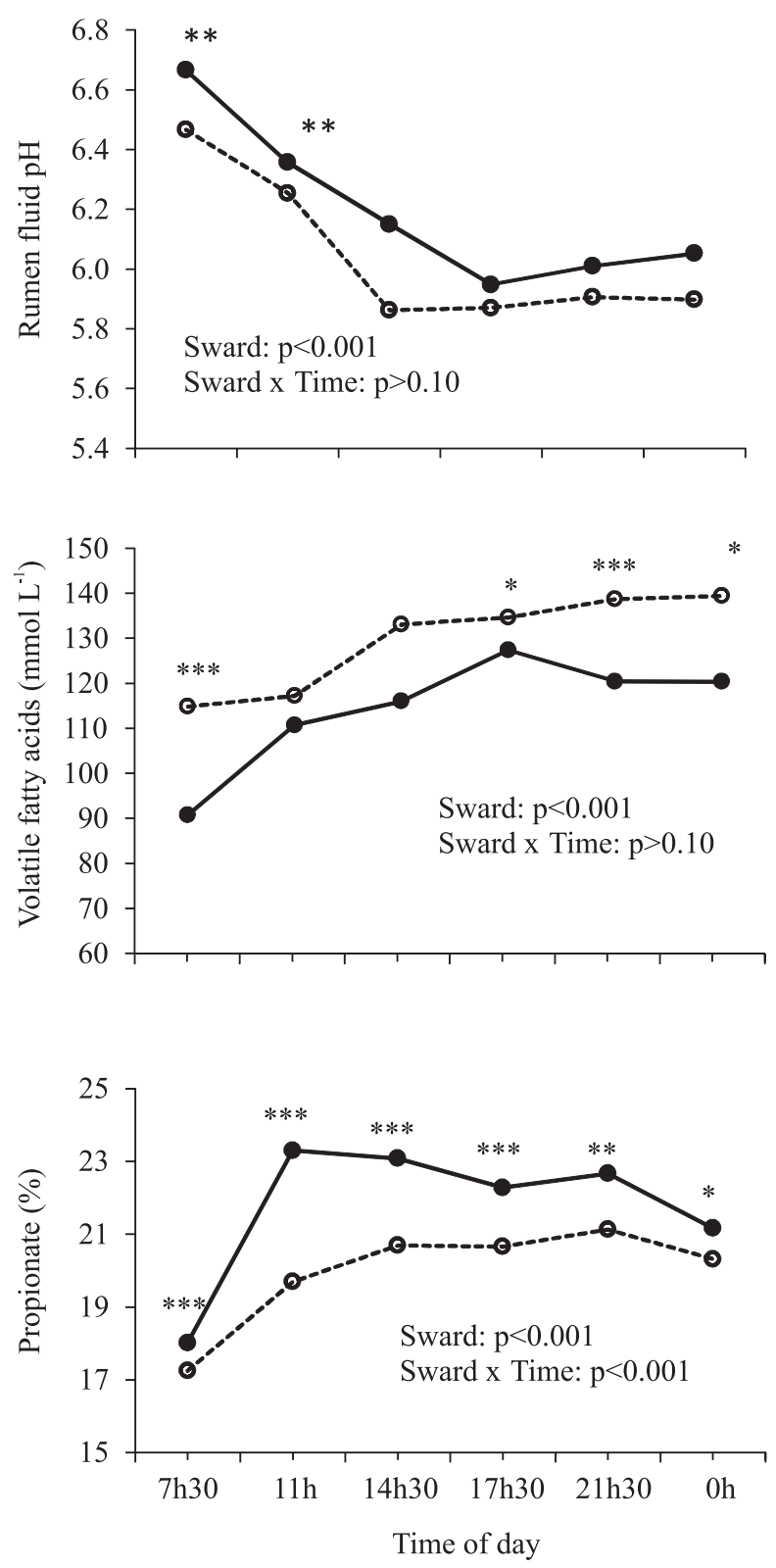

In both sward types, the decrease in rumen fluid $\mathrm{pH}$ and the increase on VFA started during the first morning grazing bout. In contrast, rumen fluid $\mathrm{pH}$ increased and VFA decreased at night, when the rumination time by hour was higher than the grazing time by hour. A similar ingestive behavior pattern was observed by Williams et al. (2005) with cows grazing Persian clover- or perennial ryegrass-dominant swards. According to these authors, this may be explained by
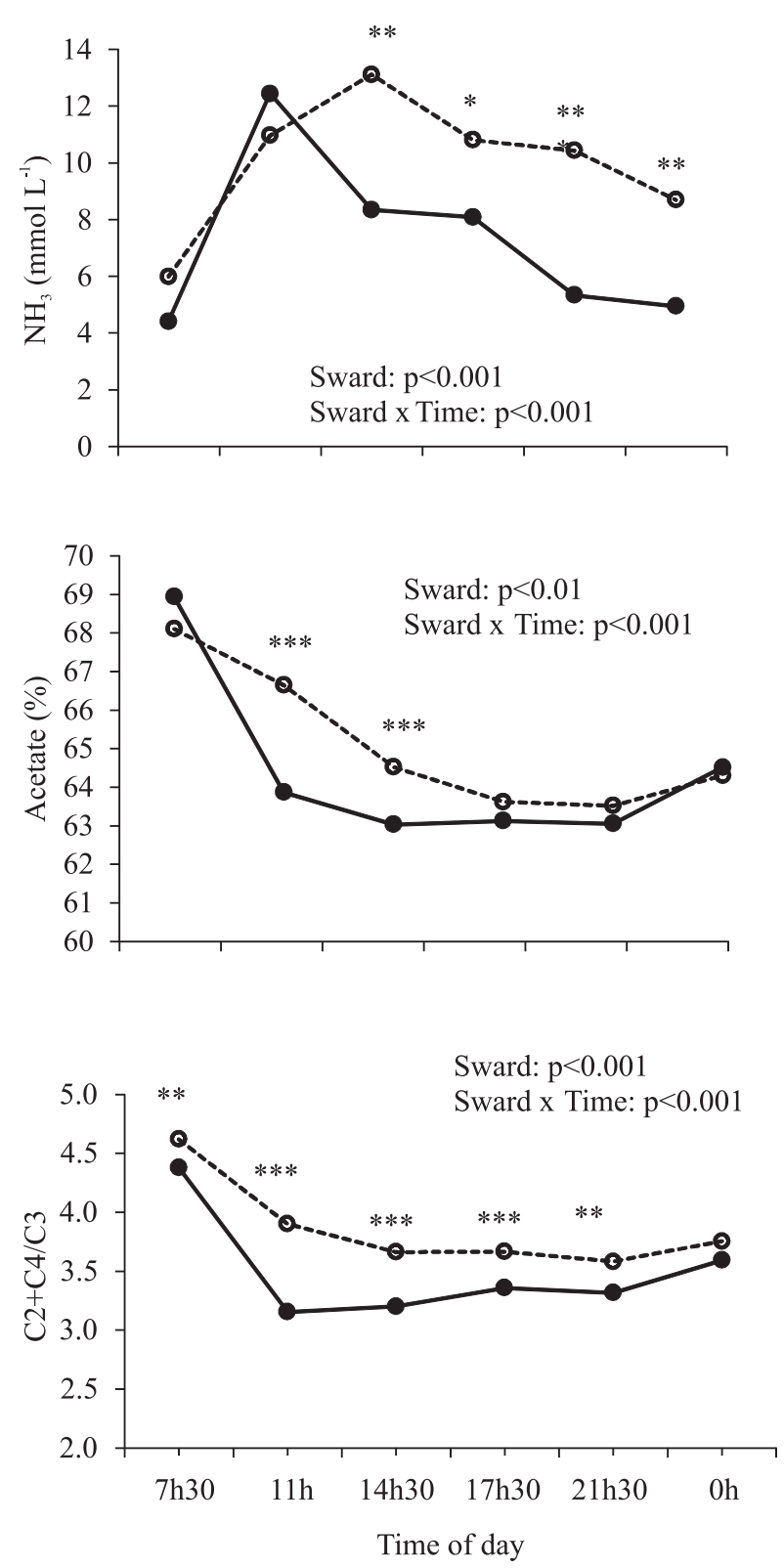

Figure 2. Diurnal ruminal fermentation patterns of cows grazing perennial ryegrass alone $(\bullet)$ or a mixture of perennial ryegrass and white clover $(0)$; for each time of day *,**, and *** Significant at 5,1 , and $0.1 \%$ probability, respectively, by the Student's t-test. C2, acetate; C3, propionate; C4, butyrate. 
shifts in the balance between the rate of VFA production from ingested material, the rate of absorption of VFA, and the influence of the buffering effect of saliva. Additionally, absorption rates of VFA across the rumen wall may have been increased at night due to a lower rumen fluid volume, resulting in a higher effective surface area for absorption (Dijkstra et al., 1993). Small increases in the VFA pool immediately after the beginning of grazing are expected due to a low efficiency of chewing during eating (Boudon et al., 2006; Acosta et al., 2007). Ingestive chewing is one of the main reasons to release soluble nutrients from feeds (Chilibroste et al., 2007).

The lower lipogenic to glycogenic VFA ratio in cows grazing PRG swards was primarily due to a higher proportion of propionic acid. This result shows that ruminal propionate production is clearly associated to high water-soluble carbohydrate contents on grass swards, despite the higher herbage intake and VFA concentration on mixed swards. Similar results have been observed in perennial ryegrass and white clover at grazing experiments (Beever et al., 1986), and substrate has played a major role on fermentation end products (Noziere et al., 2011).

The daily pattern of $\mathrm{NH}_{3}$ concentration was different (interaction between sward type and time of day: $\mathrm{p}<0.001$ ) between the PRG and the GC swards (Figure 2). After morning milking, $\mathrm{NH}_{3}$ concentration increased in cows grazing both sward types, but in the afternoon $\mathrm{NH}_{3}$ decreased more intensively in cows grazing the PRG swards. After evening milking, $\mathrm{NH}_{3}$ was higher in the GC swards, probably because the crude protein $(\mathrm{CP})$ concentration of the offered herbage was higher on the mixed swards than on the PRG swards (176 vs $159 \mathrm{~g} \mathrm{~kg}^{-1}$ ). Moreover, the CP content probably declined more intensively in ryegrass alone than on mixed swards with sward depletion. In perennial ryegrass swards, Delagarde et al. (2000) observed that CP decreased with sward depletion, due to the decline in the proportion of leaf and green leaf during the day in a strip-grazing management. However, no similar experiments have been conducted with mixed swards.

Cows grazing young and old swards had a similar daily grazing distribution (Figure 3 ). However, cows grazing swards with longer regrowth spent more time grazing after morning milking in comparison to cows that grazed swards with shorter regrowth $(\mathrm{p}<0.01)$. Cows grazing the youngest swards spent more time grazing in the afternoon and in the evening. The daily pattern of rumination was similar between regrowth ages, but rumination time was higher on cows grazing oldest swards in the afternoon and at night.

The loss of motivation to graze at evening on the oldest swards could indicate a higher level of depletion (0.69 vs 0.54$)$ and a lower intake rate than on the youngest swards. According to Delagarde et al. (2001), the intake of grazing dairy cows is strongly correlated with the proportion of the defoliated sward height. Orr et al. (2004) observed reductions on bite mass and intake rate with sward height reduction. Bite mass on mature swards is also affected by the presence of "barrier" components in the swards, such as stems and dead material (Drescher et al., 2006). In the present study, live sheath and stem were $8.5 \%$ higher on the youngest swards.
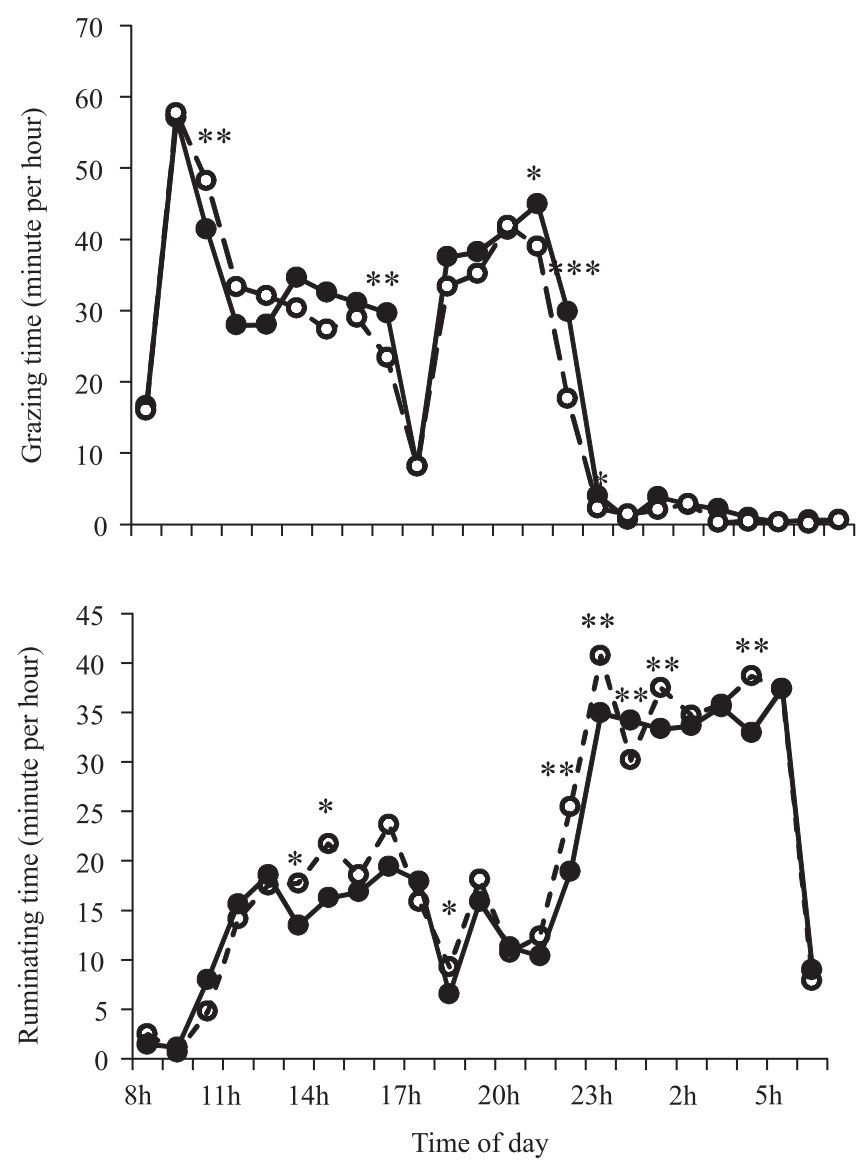

Figure 3. Diurnal grazing and ruminating patterns of cows grazing perennial ryegrass alone or a mixture of perennial ryegrass and white clover with $19(\bullet)$ or 35 days of regrowth (०); for each time of day $*, * *$, and $* * *$ Significant at 5, 1, and $0.1 \%$ probability, respectively, by the Student's t-test. 
Cows grazing young and old swards had a different daily pattern of ruminal fermentation, except for $\mathrm{NH}_{3}$ concentration (Figure 4). In young swards, rumen fluid $\mathrm{pH}$ decreased and total VFA concentrations increased from the first milking (7h30) until $0 \mathrm{~h}$, whereas in old swards rumen fluid $\mathrm{pH}$ increased and total VFA concentration decreased after evening milking (17h30).

The increase in rumen fluid $\mathrm{pH}$ and the reduction in VFA concentration on the oldest swards, after the second milking, was clearly a function of the lower intensity of ruminal fermentation, independently of the time spent grazing, which was not much higher in the youngest swards. This reduction could be associated to a lower intake rate (Gregorini et al., 2009) and to a lower proportion of green leaf at the end of the paddock in the oldest swards. These data are in agreement with Williams et al. (2005), who concluded that the lower rumen fluid $\mathrm{pH}$ level observed was a function of the higher intake rate of cows grazing at high herbage allowance. In the present study, swards were compared with similar herbage allowance at $5.0 \mathrm{~cm}$ above ground level, but oldest swards had a much higher pre-grazing herbage mass and, consequently, a lower herbage allowance to ground level.
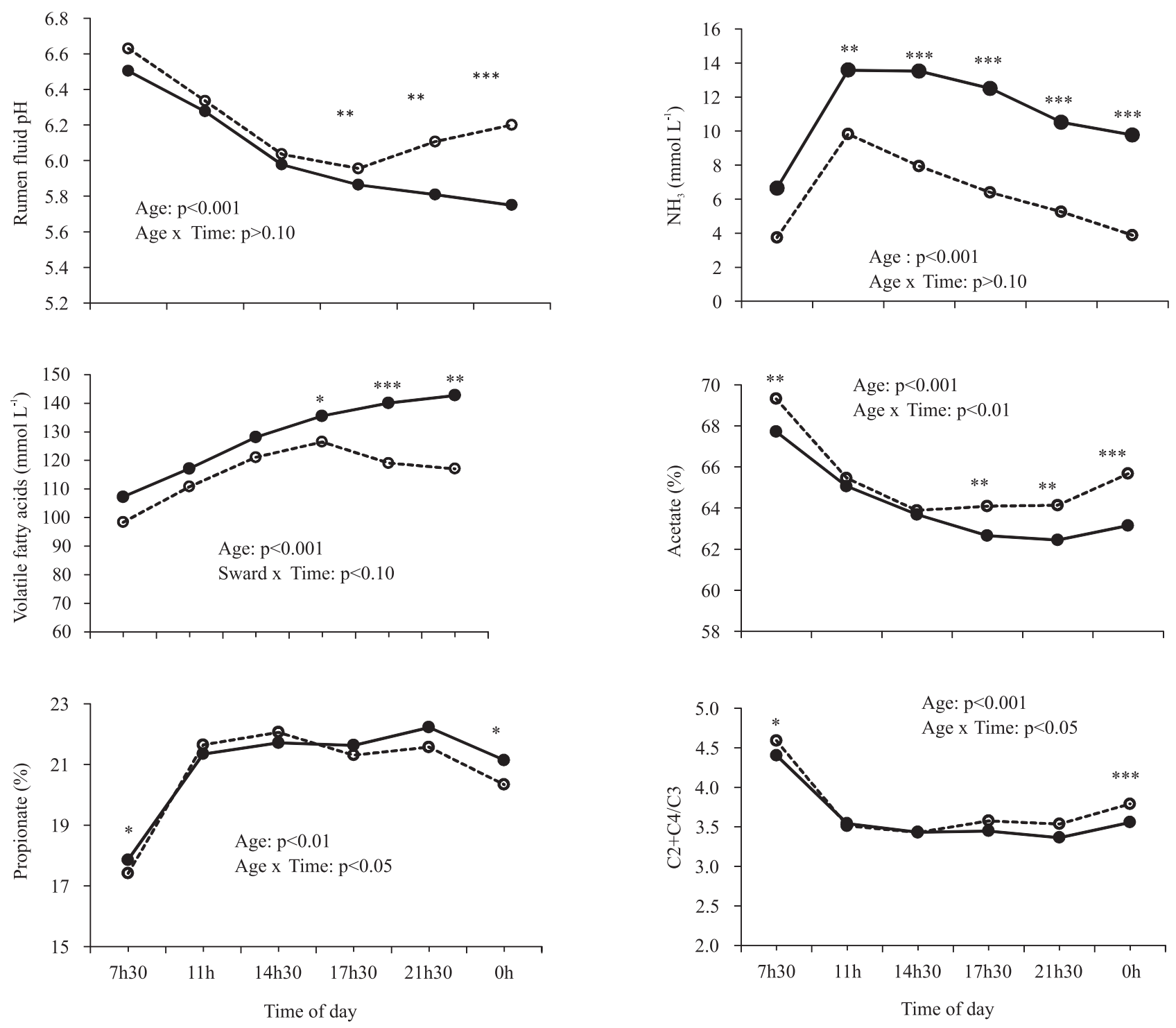

Figure 4. Diurnal ruminal fermentation patterns of cows grazing perennial ryegrass alone or a mixture of perennial ryegrass and white clover with $19(\bullet)$ or 35 days of regrowth $(\circ)$; for each time of day *,**, and ***Significant at 5 , 1 , and $0.1 \%$ probability, respectively, by the Student's t-test. C2, acetate; C3, propionate; C4, butyrate. 
Ruminal $\mathrm{NH}_{3}$ concentration increased after morning milking, but decreased in the afternoon and at night in cows grazing swards of different ages. However, the oldest swards resulted in lower ruminal $\mathrm{NH}_{3}$ concentration at all sampling times. The higher $\mathrm{NH}_{3}$ concentration in cows grazing youngest swards, during the day, could be a result of the higher $\mathrm{CP}$ concentration in all layers. The CP content of the offered herbage was much higher $\left(+41 \mathrm{~g} \mathrm{~kg}^{-1}\right)$ in the young regrowth than in the old regrowth.

Despite the greater time spent grazing on the GC and the youngest swards after evening milking, differences in ruminal $\mathrm{pH}$ and VFA concentration were more evidenced between the oldest and the youngest swards than between the GC and the PRG swards. These results show that white clover inclusion was not enough to avoid decreases in ruminal fermentation when cows grazed lower layers in older swards. In fact, the daily pattern of ruminal fermentation has not been associated to time spent grazing, probably due to differences in intake rate (Orr et al., 2004) and herbage nutritive value (Delagarde et al., 2000).

The greater motivation to graze early in the morning in the GC and the youngest swards, when cows entered a new paddock, seems to be associated to hunger factors, despite the similar daily grazing time. The short-term control of feed behavior is dependent of satiety signals, mainly those related to rumen fill and VFA concentration as an additive effect (Faverdin et al., 1995). In the present study, the VFA concentration was higher $(p<0.001)$ in cows grazing the GC and the youngest swards than in those grazing the PRG and the oldest swards during the day. Orr et al. (2004) observed that intake rate and bite mass were relatively higher when heifers were first introduced into new paddocks, with tall and leafy swards, due to the fact that they were hungry after being moved from the previous depleted swards.

\section{Conclusions}

1. Time spent grazing is not associated with the intensity of ruminal fermentation.

2. The pattern of ruminal fermentation clearly depends on the changes that occur as different sward layers are grazed.

3. Substrate type has a great impact on the lipogenic to glucogenic VFA ratio, which can change with sward type and age regrowth.

\section{References}

ACOSTA, A.; BOUDON, A.; PEYRAUD, J.L. Species and variety of herbage affects release of cell contents during ingestive mastication in dairy cows fed indoors. Animal Feed Science and Technology, v.132, p.28-48, 2007.

BAUMONT, R.; COHEN-SALMON,D.;PRACHE, S.; SAUVANT, D. A mechanistic model of intake and grazing behaviour in sheep integrating sward architecture and animal decisions 2004. Animal Feed Science and Technology, v.112, p.5-28, 2004.

BEEVER, D.E.; LOSADA, H.R.; CAMMELL, S.B.; EVANS, R.T.; HAINES, M.J. Effect of forage species and season on nutrient digestion and supply in grazing cattle. British Journal of Nutrition, v.56, p.209-225, 1986.

BOUDON, A.; ACOSTA, A.; DELAGARDE, R.; PEYRAUD, J.L. Release of cell contents and comminution of particles of perennial ryegrass herbage during ingestion by dairy cows fed indoors or grazing. Grass and Forage Science, v.61, p.205-217, 2006.

CHAPMAN D.F.; PARSONS, A.J.; COSGROVE, G.P.; BARKER, D.J.; MAROTTI, D.M.; VENNING, K.J.; RUTTER, S.M.; HILL, J.; THOMPSON, A.N. Impacts of spatial patterns in pasture on animal grazing behavior, intake, and performance. Crop Science, v.47, p.399-415, 2007

CHILIBROSTE， P.; SOCA， P.; MATTIAUDA， D.A.; BENTANCUR, O.; ROBINSON, P.H. Short term fasting as a tool to design effective grazing strategies for lactating dairy cattle: a review. Australian Journal of Experimental Agriculture, v.47, p.1075-1084, 2007.

DELAGARDE, R.; PEYRAUD, J.L.; DELABY, L.; FAVERDIN, P. Vertical distribution of biomass, chemical composition and pepsin-cellulase digestibility in a perennial ryegrass sward: interaction with month of year, regrowth age and time of day. Animal Feed Science and Technology, v.84 p.49-68, 2000

DELAGARDE, R.; PEYRAUD, J.L.; PARGA, J.; RIBEIRO FILHO, H.M.N. Caractéristiques de la prairie avant et après un pâturage: quels indicateurs de l'ingestion chez la vache laitière? Rencontres Autour des Recherches sur les Ruminants, v.8, p.209-212, 2001

DEWHURST, R.J.; DELABY, L.; MOLONEY, A.; BOLAND, T.; LEWIS, E. Nutritive value of forage legumes used for grazing and silage. Irish Journal of Agricultural and Food Research, v.48, p.167-187, 2009.

DIJKSTRA, J.; BOER, H.; VAN BRUCHEM, J.; BRUINING, M.; TAMMINGA, S. Absorption of volatile fatty-acids from the rumen of lactating dairy cows as influenced by volatile fatty acid concentration, $\mathrm{pH}$ and rumen liquid volume. British Journal of Nutrition, v.69, p.385-396, 1993.

DRESCHER, M.; HEITKONIG, I.M.A.; RAATS, J.G.; PRINS, H.H.T. The role of grass stems as structural foraging deterrents and their effects on the foraging behaviour of cattle. Applied Animal Behaviour Science, v.101, p.10-26, 2006.

FAVERDIN, P.; BAUMONT, R.; INGVARTSEN, K.L. Control and prediction of feed intake in ruminants. In: JOURNET, M.; GRENET, E.; FARCE, M. H.; THÉRIEZ, M.; DEMARQUILLY, 
C. (Ed.). Recent developments in the nutrition of herbivores. Versailles: INRA Editions, 1995. p.95-120.

GREGORINI, P.; GUNTER, S.A.; BECK, P.A.; CALDWELL, J.; BOWMAN, M.T. Short-term foraging dynamics of cattle grazing swards with different canopy structures. Journal of Animal Science, v.87, p.3817-3824, 2009.

INSTITUT NATIONAL DE LA RECHERCHE AGRONOMIQUE. Alimentation des bovins, ovins et caprins: besoins des animaux valeurs des aliments. Versailles: Editions Quae, 2007. 307p.

LITTELL, R.C.; HENRY, P.R.; AMMERMAN, C.B. Statistical analysis of repeated measures data using SAS procedures. Journal of Animal Science, v.76, p.1216-1213, 1998.

NOZIERE, P.; GLASSER, F.; SAUVANT, D. In vivo production and molar percentages of volatile fatty acids in the rumen: a quantitative review by an empirical approach. Animal, v.5, p.403-414, 2011.

ORR, R.J.; RUTTER, S.M.; YARROW, N.H.; CHAMPION, R.A.; ROOK, A.J. Changes in ingestive behaviour of yearling dairy heifers due to changes in sward state during grazing down of rotationally stocked ryegrass or white clover pastures. Applied Animal Behaviour Science, v.87, p.205-222, 2004.

PEYRAUD, J.L.; LE GALL, A.; LUESCHER, A. Potential food production from forage legume-based-systems in Europe: an overview. Irish Journal of Agricultural and Food Research, V.48, p.115-135, 2009.

RIBEIRO FILHO, H.M.N.; DELAGARDE, R.; PEYRAUD, J.L. Inclusion of white clover in strip-grazed perennial ryegrass swards: herbage intake and milk yield of dairy cows at different ages of sward regrowth. Animal Science, v.77, p.499-510, 2003.

STEINSHAMN, H. Effect of forage legumes on feed intake, milk production and milk quality - a review. Animal Science Papers and Reports, v.28, p.195-206, 2010.

WILLIAMS, Y.J.; WALKER, G.P.; DOYLE, P.T.; EGAN, A.R; STOCKDALE, C.R. Rumen fermentation characteristics of dairy cows grazing different allowances of Persian clover- or perennial ryegrass-dominant swards in spring. Australian Journal of Experimental Agriculture, v.45, p.6641-6675, 2005.

Received on August 23, 2011 and accepted on February 13, 2012 